\title{
THE WONDERFUL DEER MOTIF SEQUENCE (AATH 401/ATU 400) AS AN INDIGENOUS TOTEMIC-LIKE SUBSTRATUM İN THE CENTRAL EURASİAN HEROİC EPİC TRADITTIONS
}

\begin{abstract}
This paper focuses on the ecological as well as historical foundations and genesis of the motif sequence common to several Central Eurasian heroic epics - the different versions of the North Caucasian Nart and of the Mongolic (Oirat) Geser epic. The core of the episode is the otherworldly hunt of the protagonist, where he tries to bring down a wonderful doe that appears in front of him. Later this animal transforms into the daughter of the sun or of a foreign king/lord/prince, while in the Mongolian Geser epic she is the daughter of the Dragon King. Although the name of the hero and some motifs in the Mongolian epic tradition are of Tibetan origin, the main motifs and the structure of the Chapters 4 and 6 (SCHMIDT 1839) are of North Central Asian (Scytho-Siberian and probably Hsiung-nu) ${ }^{1}$ origin: two heroes, hunting, the fleeing wonderful deer, traces leading to the castle, where the pursued animal is no longer waiting for its' pursuers in the shape of a deer, but as a woman, and at last marriage. ${ }^{2}$ With the complex comparativehistorical and "tradition ecological" (e.g. HARVILAHTI 2014: 18) methods and approaches to the intertwine of nature (environment) and culture including "religious" beliefs, ideas and concepts, following a unit-based (motif oriented) approach, I intend to prove, that even if some narrative figures are originated from the Tibetan Buddhist cultural area, the biocultural and ecological background, and mythical (epic) function of the characters and the entire motif sequence are inherited from the Siberian shamanic and the South Siberian/Southern North Asian (SNA) totemic-like beliefs and rituals (e.g. Evenki ikenipke 'renewal of life;' HAMAYON 1992: 134, 136) ${ }^{3}$ of Palaeolithic, Neolithic, Bronze and Iron Age hunter-gatherer societies.
\end{abstract}

Keywords: epic motif, mythologem, narrative structure, genesis, Gesar epic.

\section{Introduction}

The heroic epics of the Tibetan King Ge-sar and the Mongolic Geser Khan have highly complex origins. The former one is an oral epic cycle narrating the heroic deeds of the hero Ge-sar, lord of the kingdom of gLing, probably dating from the $12^{\text {th }}$ century, but according to other theories and argumentations maybe a much earlier epoch, between the $1^{\text {st }}$ and $6^{\text {th }}$ centuries CE (JIANGBIAN 1985: 37-38; LI 2001: 332). The extremely different national versions of multiple origins are still sung widely throughout all Central Asia by hundreds of bards in Tibetan, Lepcha, Mongolic (Khalkha; HARVILAHTI 1996: 40-45; Oirat: Olot/Ööld, KARA 1970: 214; and Volga Kalmyk, HeISSIG 1987: 1155-56; Buryat, HeISSIG 1987: 1158), Yugur and Salar (DAMDINSÜREN 1957: 56; HARVILAHTI 1996: 43; RICHTSFELD 2005). Its so-called "classic" version could be originated from the north eastern Tibetan Province Amdo (HERMANNS 1965: 295).

${ }^{1}$ The different variants of the oral narrative in question (AaTh 401/ATU 400) which had been recorded from the Huns (Central Asia, Caucasus, Eastern Europe, between the $4^{\text {th }}$ and the $6^{\text {th }}$ centuries CE; vide: Salaminius Hermias Sozomenus [CE 415; WALFORD 1855: 304-5; Procopius of Caesaria; DeWING 1962: 86-91; Jordanes; both 6th c.; MIEROW 1915: 85-6), have to be Hsiung-nu or at least North Central Asian (or Southern North Asian/SNA) origin. See also: ALTHEIM 1969: 238.

${ }^{2}$ All this may have been valid for the pre-Buddhist worldview of the Tibetans as well, although we do not know a single Tibetan version of Ge-sar epic (Gesar of gLing), which would include the entire and complete motive sequence in question, as known from the Mongolic versions of the Epic of King Geser; Olot/Ööld [Oirat], Buryat, Kalmyk, etc.; see also: HAMAYON 2004; HERMANNS 1965: 319-326; 435-458).

${ }^{3}$ See also for its biocultural context: "Each spring the migrations of the vast herds repeat, symbolically, the renewal of life [...]. Cows lead their almost-year-old calves [...]. Half the world away, in Siberia and Scandinavia, the urge of spring seizes the wild reindeer. [...].” (italics mine; CALEF 1981: 23).

${ }^{4}$ Referring to Herrmann 1990: 485, Nekljudov 1984: 145, and Stein 1959: 59-60, Lauri Harvilahti mentioned versions among the "Tunghus tribes" as well (HARVILAHTI 1996: 40), but the authors referred by him have not mentioned in this context any Tungus societies at all. There are of course folktales that share common motifs (e.g. A 530, A 531; B 742; F 401.7.; K 1335, etc.; vide e.g.: HeISSIG 1983a: 18, 25; 1985: 1152) with the Geser/Gesar epic vice versa such as an Oroqen one (QI LIANXIU and LIU SHIHUA 1981: 246-255; RICHTSFELD 2005: 237), but there is no a single version of the heroic epic tradition in question among the Tungusic tribes (Nanai, Orok/Uilta, Ulch/Olcha, Oroch, Udege/Udihe, Even, Evenki, etc.). However, there has been collected an Evenki folktale of Buryat origin, in which the original name of the hero had been replaced by the name of Geser (Həhər), but the sujet of the folktale is far from any Buryat or other 


\section{The Wonderful Deer Episode in the Xylograph Edition (1716) ${ }^{1}$ of the Mongolic (Oirat: Olot) Geser Epic}

The Wonderful Deer motif sequence (AaTh 401: The Princess Transformed into Deer; AARNE and THOMPSON 1961: 131) is completely absent in any version of the Tibetan Ge-sar epic published up to now. However, this fact is relatively little-known among the researchers of Central Eurasian oral epic due to an academic paper, which has been published almost half a century ago.

\subsection{An Article about the Wonderful Deer - full of false and misleading information}

There is a brief German article on the assumed existence of the Wonderful Deer in the Tibetan corpus (HUMMEL 1973), which has been republished in a somewhat mutilated version (1993) as well as the English translation of the latter (1998). The paper is based on a fatal misunderstanding and on incorrect assumptions. First, Hummel gave the completely misleading title 'Der wunderbare Hirsch im Ge-sar-Epos' to his original paper (HUMMEL 1973), as if there were any Tibetan version (Hummel wrote the Tibetan form Ge-sar instead of the Mongolian Geser in the title) including the motif sequence in question. Actually, he used no more than three text variants for his minor study, namely (1) the first and only German translation of the xylograph edition of a Mongolian (Oirat: Olot) version of the Geser epic, published in 1716 in Beijing (SCHMIDT 1839); (2) a northeastern Tibetan version from the Amdo region (HERMANNS 1965: 435-458; Hummel falsely wrote „eastern" in spite of the clear geographical location given by Hermanns on the page 371: "3. die nordöstliche in A mdo"); (3) and a western Tibetan version (FRANCKE 1902; new edition 1968). However, only the Mongolian version includes the Wonderful Deer episode, thus the indication of the Tibetan Ge-sar in the title is quite fallacious. Additionally, he begins his original paper with the following misinformation:

Die Fülle der mythologischen Motive in der Ge-sar-Sage, dem grossen Heldenepos der Tibeter, ist längst noch nicht erschöpft (HUMMEL 1973: 37).

He mentions the Mongolian version of the disparate epic traditions which exclusively includes the Wonderful Deer episode, in contrast of all known Tibetan versions, just after his short but entirely misconceived introduction. This very brief paper was republished in a volume under the following title: Mythologisches aus Eurasien im Ge-sar-Heldenepos der Tibeter. The editor did not just give this incorrect title to the volume of S. Hummel's collected works, but he abridged the original version of the paper in question arbitrarily. The original German version was longer by two initial paragraphs, which begins with the sentence above. In these paragraphs, which have been extracted from the later editions, the author refers only to the Mongolian version of the Geser epic (SCHMIDT 1839). Unfortunately, Hummel continues his misinformation as follows:

Die durch Schmidt aus dem Mongolischen übersetzte Version der Ge-sar-Sage, die nach unserer heutigen Kenntnis zweifellos auf eine tibetische Vorlage zurückgeht, ist besonders reich an Mythenparallelen ältester Tradition (HUMMEL 1973: 37; in the 2nd paragraph).

Such a negligence is entirely inacceptable, since Matthias Hermanns wrote very clearly contrarily to the above statement in the Einleitung of his significant work, which was known by Hummel according to his references:

Die Übersetzung von Schmidt zeigt ganz deutlich, daß die mongolische Ge sar-Sage von der tibetischen völlig verschieden ist (HERMANNS 1965: 373).

The above example demonstrates that "to the best of our knowledge," the Mongolian (Olot) version of the Geser epic is (almost) completely different from any Tibetan version, as it has been elicited by DAMDINSÜRĖN (1957: 164) and by HERMANNS (1965) earlier. ${ }^{2}$

\subsection{The Otherworld and Mother of the Animals}

There is a close conceptual link between the Wonderful Deer episode of the Central Eurasian heroic epics, among them the Mongolian Geser epic and the archaic religious worldview of the given societies. Although the Mongolian narrative is highly syncretic in its content and form, including several motifs,

versions of the Geser epic (Напı Нивип Нəhər Bogdo/Хани Хубун Хохор Богдо; VASILEVIČ and AL'KOR 1936: 171175; URAY-KÖHALMI 1980: 77).

1 "According to Mongolian traditions this version is based on the activity of story-tellers from Kokonor who lived in 1630 [...] (STEIN 1981: 8; see also: DAMDINSÜREN 1957: 56; KARA 1970: 214).”

${ }^{2}$ Hummel did not used, among others, the book written by Sergej Andreevič KozIN (Geseriada: skazanie o milostivom Geser-Khane iskorenitele desjati zol v desjati stranakh sveta, Moscow and Leningrad, 1935), in which the author has already explicitly revealed that the first 7 chapters of the Mongolian xylograph edition (1716) have been formed in an independent way, differing from the Tibetan epic tradition substantially (ibid. 245). 
mythologems or archetypes and religious concepts, but the otherworldly hunt on the doe constitutes its most ancient substrate. Hummel - at least - realized that the pursuit of the hind leads the protagonists into the Otherworld (HUMMEL 1998: 53).

Hummel was on the opinion, that the deer has a chthonic character that is an entity of the underworld, as in the Greek 'mythology.' I would agree with him in case the motif in question would be incorporated into the Mongolian epic from the Greek 'mythology and folklore.' But according to the multiple evidences (Central Asian oral epics, shamanic rituals, Palaeolithic, Neolithic and Bronze Age rock carvings and landscapes, closely interrelated human and natural environment), the motif sequence of the hunt on the reindeer doe (Rangifer tarandus) was inherited into the Turko-Mongolic Geser and Alpamysh epic traditions from the indigenous North Central Asian (or SNA; see: PEDERSEN 2001) pastoral nomadic and Southern Siberian hunter-gatherer ecocultural area and worldview(s), thus the hind (Mother or Master of the Animals, see: HOLMBERG [HARVA] 1927: 463-71, 496-523, esp. 501-2; HARVA 1938: 477; ZERRIES 1987: 22-26; HULTKRANTZ 1994: 357-61, esp. 360, 366-67; VITEBSKY 1995: 32; JACOBSON-TEPFER 2015; game-giving spirit; HAMAYON 1992: 136-37; 1996 [1994]: 79-80) is originally not an exclusive principle of the underworld, but it penetrates all three, the earthly and otherwordly spheres, both underworld and celestial, which concept is inherently interconnected in the complex worldview of traditional animistic, shamanistic and partially totemic (PEDERSEN 2001) Inner Asian (SNA) ecocultures. That means that the reindeer doe does not exclusively related to the underworld but also to the celestial sphere ${ }^{1}$ (see: COLARUSSO and SALBIEV 2016: 160-161; MARTYNOV 1991: 229 ${ }^{2}$ etc.), while the hero (hunter/shaman) represents his society.

One can see here the amalgamation of two different epic (and religious) traditions. One of them is the Tibetan Buddhist layer, ${ }^{3}$ while another one is the Central Asian epic (and pre-Buddhist) traditions (e.g. the Alpamysh). Referring to the partially divergent origins and evolution of the narrative motifs and structures of Mongolic Geser and Tibetan Ge-sar epics let us see two other significant opinions by the Mongolist György Kara and the Tibetologist Matthias Hermanns. Kara wrote in his brief introduction for the Hungarian translation of the Chapter 6 of the Mongolian xylograph edition, that it is not the translation of a written original, but a new creation transmitted by folklore (KARA 1971: 63). Hermanns had formed a more characteristic opinion.

Die mongolischen, die burjätisch-mongolischen und die tibetischen Versionen unterscheiden sich sehr nach Form und Inhalt. (...) Die wesentlichen Teile der mongolischen, tibetischen und burjätischen Versionen stimmen nicht überein und beschreiben die Ereignisse verschieden. Von dreizehn Kapiteln einer mongolischen Fassung haben nur zwei einige Analogien mit der Tibetischen. Das sind die Kapitel über die Geburt des Ge sar und über den Krieg mit den Scharaigolen. Die übrigen elf Kapitel bestehen ganz klar aus selbständigen, mongolischen Überlieferungen, die in der tibetischen Fassung keine entsprechenden Kapitel haben...Doch auch die zwei ersten Kapitel haben ein mongolisches Milieu (DAMDINSÜRĖN 1957: 163-164; HERMANNS 1965: 373).

Hence, the chapter under discussion is one of the stories, whose plot, motif structure and environment are fully independent from every version of the Tibetan Ge-sar epic.

\subsection{Chapter 6: "How Geser was Changed into a Donkey" (1716, Xylograph Edition)}

The fourth (SCHMIDT 1839: 112-158) and the shortest chapter, ${ }^{4}$ the sixth one (273-282) contain the hunt of the doe and the succession of motifs has to be originated from North Central Asia, out of the range of Tibetan Buddhism, which constitutes just a shallow superstratum in the story. By doing this, it contributes to its syncretic nature. Before the Wonderful Deer episode, Chapter 6 includes several previous scenes with the visit of the powerful Monster (Ogre) who turns Geser into a donkey (THOMPSON 1956, II: 18; D 132.1; HEISSIG 1987: 1157). The people of the protagonist asks for the help of Lady Aju Mergen. She puts on the shape of the elder sister of the Ogre and goes to the fortress of him to recover the beautiful Rogmo, Geser's wife, who had allied herself with the Ogre, and Geser himself, who is kept there as a donkey. She manages to lure out the Monster, and she gets on the road with the donkey-Geser, who recovers his original shape with

${ }^{1}$ Conf.: Cosmic Hunt: Thompson F59.2. Pursuit of game leads to upper world. (THOMPSON 1955-58: 3: 12).

2 “Solar reindeer. Tom' river petroglyph (Okladnikov and Martynov 1979: pl. 24)."

${ }^{3}$ The Mongolian word khurmast (in the idiom khurmast tèngèr; Buryat khan-khyurmast téngèr) is a copy from Old

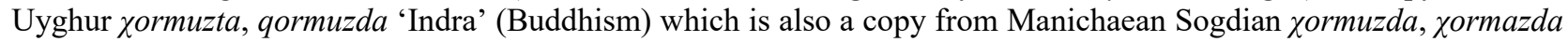
$(\chi w r m w z \delta, \chi w r m z \delta)$ 'prehistoric man; Urmensch' (GABAIN 1974: 336).

${ }^{4}$ It is not simple the shorter chapter, but a shorter, simplistic version (textus simplicior; KARA 1970: 217) of a longer epic; see the next passage of recent paper. 
time. One can find the Wonderful Deer story both in German (SCHMIDT 1839: 279) and in English translation (BAWDEN 2003: 238).

\section{The Wonderful Deer Episode in the Saint Petersburg Manuscripts $\left(16-17^{\text {th }} \mathbf{C}\right.$.) and in the Beijing/Hohhot Edition (1956) of the Mongolic (Oirat) Geser Cycle}

There are two manuscripts deviating from each other just slightly (C 296 and C 441), written in Uyghuro-Mongol script in Oirat dialect preserved in the Institute of Oriental Manuscripts of the Russian Academy of Sciences in Saint Petersburg (former Leningrad), including palaeographically (e.g. diacritical marks) more ancient (esp. C 296, 16th c.; DAMDINSÜREN 1957: 56, 134-35; KARA 1970: 214; 16-17th c.; HEISSIG 1983b: 22) and in their extent and episodes more exhaustive (textus ornatior; KARA 1970: 223; textus amplior; HEISSIG 1983b: 21-23) versions, which incorporate the episode of the Chapter 6 of the xylograph edition (1716) as well. Thus, the latter is just a so-called brevior version (or textus simplicior; KARA 1970: 217) of the former ones. The text of these manuscripts has been published in 1956 in Beijing and Hohhot ${ }^{1}$ with minor differences (e.g. see: KARA 1970: 223, footnote 30), and constitutes the chapter 11 of the two volumes edition (1956, 2: 52-101).

György Kara compared the texts of the Chapter 6 of the 1716 Beijing edition and of the two St. Petersburg manuscipts as a list of the episodes' extracts (C 296, C 441; KARA 1970: 217-223).

The passage 29 (KARA 1970: 220) has been summarized by Heissig (HEISSIG 1983b: 45-46).

The most significant difference between the plenior and the brevior version is that there remained just a marriage proposal of the protagonist in the latter ("If I pull it out, will you be my wife? « She said: » Yes, I will be your wife. «"), while in the more detailed manuscipts and in the Beijing 1956 version, the marriage has been realised, although in a somewhat corrupted form (DAMDINSÜREN 1957: 138; HEISSIG 1983b: 46-47, footnote 95). The clear indication that this marriage between the ogre's sister (mangrus-un egeči) and Geser has really happened occurs somewhat later (HEISSIG 1983b: 49).

Kara has also published the critical edition of the three longer versions of the epic tradition (C 296, C 441, Beijing 1956; KARA 1970: 224-246). The most relevant passages referring to the motif sequence and narrative structure under discussion are on the page 240.

The passage, which clarifies the ambiguous part of the marriage between Geser and the otherworldy Wonderful Deer, which transformed into the ogre's sister is as follows:

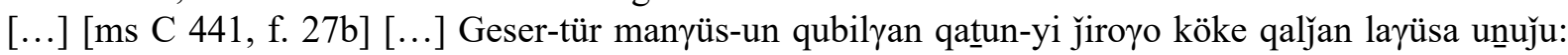
Geser-tür kürüget’ ayilat’qqar-un: [...] (KARA 1970: 240)

\section{On the Structure of the Wonderful Deer Motif Sequence of the Mongolic Epics}

One can find a number of fragmentary epic and tale variants (e.g. KOPPE 1993: 110-129) that have lost one or more motifs of the sequence in the course of the formation and multiple evolution of the narrative structure. Another significant factor of such multidirectional developments (formation of folklore variants) are the various changes in the complex belief system and worldview, on which the myths, rituals and ritual texts are based.

The structural scheme below is the more or less original and most archaic motif sequence, reconstructed by the author of this paper according to the related folklore and field research data of social and cultural anthropology (among others: HAMAYON 1996 [1994]: 79; VITEBSKY 1995: 32; COLARUSSO and SALBIEV 2016: 160-181; etc.):

1. A male person (hunter/shaman) pursues a hind (reindeer doe); the symbolic meaning of this motif, which is based on the metaphorical link between ecological perception and its symbolic imitation: Hunting Journey / Shamanic Journey.

2. Due to some unseen force he cannot capture the hind: Unsuccessful Hunt / Celestial Order.

3. The hind leads the hunter to the other side of a river (shallow/lake/mountain pass): Other side / Otherworld.

4. The deer turns into or regains the shape of a woman: Belief in a Totemic-like Transformation / Imitation of (a Totemic) Transformation.

5. The hunter marries this woman, who thereby becomes the ancestress of the clan (Mother/Master of the Animals concept): Marriage / Fertility.

\footnotetext{
${ }^{1}$ Kökeqota; Arban jüg-ün ejen Geser qag்an-u tuğuji orosiba, vol. 2,; KARA 1970: 212; HEISSIG 1983b: 11; the latter scholar called it as "Pekinger Fortsetzung" and the 1716 version as "Pekinger Blockdruck").
} 
6. Finally, they establish a new home/clan in this abundant territory where the hind has led him (the shaman/hero returns to his community): Return from the Hunting Journey / Return from the Shamanic Journey.

Several ethnographic records of certain Siberian shamanic rituals demonstrate the semantic and conceptual correlations between hunting (Motif 1) and seduction (in the narratives: marriage; Motif 5; in the ritual actions: seduction and marriage: see below), as well as between these rituals and the folk narrative tradition in question. The ontological category of the animal prey is universally female: a circumstance that has been reflected in the narrative (AaTh 401) as well as ritual tradition. "[...] Taking a wife is paralleled to taking game, and the hero's position is a taker's (HAMAYON 2004: 57)." In the "pre-historical" foundations and genesis of oral epic versions, the psychological motivations have played a crucial role, which motivations constitute the biocultural bases of the formation and development of the narrative patterns and ritual behaviour among the early South Siberian hunter-gatherer societies.

\section{Scytho-Siberian and Turko-Mongolic Parallels of the Wonderful Deer Concept}

The motif sequence of the hero's hunt on the "hind with a yellowish blaze" into the opposite bank of a river, lake (or later mountain pass) has several Central Eurasian parallels since the beginning of the $5^{\text {th }}$ century.

In the entire SNA narrative and ritual tradition, there is a conceptual link between the act of hunting on the (white, golden or wonderful) doe, the progenitress of the people of the male hunter (a totemic-like concept), pursued by him across the river/lake to the opposite shore (vide: TILLEY 1991: 130-133, "The cosmic river as a link between three worlds"; HELSKOG 1999; Motif 3: Otherworld), and their marriage. ${ }^{1}$ These concepts, namely the Otherworld journey and the totemic marriage refer to a North Central Eurasian pastoral nomadic biocultural space and heritage since the Neolithic rock carvings depicting anthropomorphic beings copulating with female moose on the Tom' River riverside cliffs (MARTYNOV 1991: 153; see also: JACOBSON 1983, 1993).

In the Turkic and Mongolic epic versions of the Wonderful Deer, moreover, some other motifs are common too. In this respect, the Ossetian Nart epic plays an especially important role in the reconstruction of the more or less original structural scheme of the epic under discussion. The corresponding part of the Nart epic expresses explicitly that the hunt on the Wonderful Doe leads the protagonist into the Otherworld, which motif reflects definitely the conceptual correlation between the epic and the SNA shamanic ritual tradition mentioned above.

The mythical functions of the characters in the Mongolic Geser epic have been affected by several factors during the last millennium, such as social, political and religious changes in the course of the history of different populations and ethnic groups.

\section{Conclusions}

The Tibetan Ge-sar and the Mongolic Geser heroic epic traditions are mostly of divergent origins and both have heterogenous genealogical and historical links. One can find extremely different national versions of multiple origins. As we have discussed above, the Wonderful Deer motif sequence (AaTh 401) is completely absent in any version of the Tibetan Ge-sar epic. The entire motive sequence in question is related structurally to the SNA shamanic rites of passage, as well as semantically to the North and Central Eurasian shamanic and totemic worldviews.

The core concepts of this complex belief system including the related epic and ritual traditions and riverside petroglyphs, inherently interwoven with each other, together with their all syncretic elements have to be evolved among the indigenous hunter-gatherer societies of the Palaeolithic Age and this belief system has developed further during the Neolithic, Bronze and Iron Ages in the large Southern North Asian multiethnic biocultural area and not in any other geographical areas of the world.

Bibliography

AARNE, A. and S. THOMPSON 1961. The Types of the Folktale: A classification and bibliography. Second Revision. FFC No. 184. Helsinki: Suomalainen Tiedeakatemia.

\footnotetext{
${ }^{1}$ Conf. the well-known first passage of the Secret History of the Mongols: "[1] Chinggis Qahan was born with his destiny ordained by Heaven above. He was descended from Börte Chino, whose name means 'greyish white wolf', and Qo'ai-maral, the wolf's spouse, whose name means beautiful doe, who crossed the lake and settled at the source of the Onon River at Burqan-qaldun, where Batachi-qan was born to them (italics mine; ONON 2001: 39-40)."
} 
Altheim, F. 1969. Geschichte der Hunnen. Erster Band. Von den Anfängen bis zum Einbruch in Europa. 2nd, revised Edition. Berlin: Walter de Gruyter \& Co.

BAWDEN, Ch. R. 2003. Mongolian Traditional Literature: An anthology. London: Kegan Paul.

CALEF, G. 1981. Caribou and the barren-lands. Ottawa: Canadian Arctic Resource Committee, [etc.].

Colarusso, J. and Salbiev, T. (eds). 2016. Tales of the Narts: Ancient myths and legends of the Ossetians. Translated by MAY, W. Princeton and Oxford: Princeton University Press.

DAMDINSÜRĖN, C. 1957. Istoričeskie korni Geseriady. Moscow: Izdatel'stvo akademii nauk SSSR.

DEwING, H. B. (trans.). 1962 [1928]. History of the Wars, Books VII (continued) and VIII. Procopius in Seven Volumes, V. London: William Heinemann Ltd.; Cambridge, Massachusetts: Harvard University Press.

GABAIN, A. V. 1974 [1941]. Alttürkische Grammatik. $3^{\text {rd }}$ Edition. Wiesbaden: Harrassowitz Verlag.

HAMAYON, R. N. 1992. 'Game and Games, Fortune and Dualism in Siberian Shamanism.' Pp. 134-137. In: HoppÁl, M. and J. PENTIKÄInEN (eds), Northern Religions and Shamanism. Budapest: Akadémiai Kiadó. . 1993. 'Are "Trance", "Ecstasy" and Similar Concepts Appropriate in the Study of Shamanism?' Shaman 1 (2): 3-25.

1996 [1994]. 'Shamanism in Siberia: From Partnership in Supernature to Counter-power in Society.' Pp. 76-89. In: Thomas, N. and C. Humphrey (eds), Shamanism, History, and the State. Ann Arbor: The University of Michigan Press.

2004. The Dynamics of the Epic Genre in Buryat culture: a Grave for Shamanism, a Ground for Messianism. In: Jan Jansen and Henk Maier (eds.), Epic Adventures: Heroic Narrative in the Oral Performance Traditions of Four Continents. 53-65. Utrecht: VockinginVorm LIT Verlag.

HARVA, U. 1938. Die religiösen Vorstellungen der altaischen Völker. Helsinki: Suomalainen Tiedeakatemia.

HARVILAHTI, L. 1996. 'Epos and National Identity: Transformations and Incarnations.' Oral Tradition 11 (1): 37-49.

2014. 'Textualizing an Oral Epic — Mission Completed.' Approaching Religion 4 (1): 18-24.

HEISSIG, W. 1983a. Westliche Motivparallelen in zentralasiatischen Epen. München: Verlag der bayerischen Akademie der Wissenschaften; C. H. Beck.

1983b. Geser-Studien. Untersuchungen zu den Erzählstoffen in den „neuen“ Kapiteln des mongolischen Geser-Zyklus. Opladen: Westdeutscher Verlag.

. 1987. 'Geser Khan.’ Pp. 1151-62. In: BREDnich, R.-W. (ed.), Enzyklopädie des Märchens, Vol. 5. Berlin and New York: Walter de Gruyter.

Helskog, K. 1999. 'The Shore Connection. Cognitive Landscape and Communication with Rock Carvings in Northernmost Europe.’ Norwegian Archaeological Review 32 (2): 73-94.

Hermanns, P. M. 1965. Das National-Epos der Tibeter Gling König Ge Sar. Regensburg: Verlag Josef Habbel. Holmberg (Harva), U. 1927. Finno-Ugric, Siberian. The Mythology of All Races in Thirteen Volumes, vol. IV.

New York: Cooper Square Publishers, Inc.

HultKRanTZ, Å. 1994. 'Religion and Environment among the Saami: An Ecological Study.' Pp. 347-374. In:

Irimoto, T. and T. YAmadA (ed.), Circumpolar Religion and Ecology: An Anthropology of the North. Tokyo: University of Tokyo Press.

Hummel, S. 1973. 'Der Wunderbare Hirsch im Ge-sar-Epos.' Ethnologische Zeitschrift Zürich II: 37-40. Bern: Verlag Herbert Lang \& Cie AG.

. 1993. 'Der wunderbare Hirsch im Ge-sar-Epos.’ Pp. 93-98. In: Aschoff, J. C. And SANwaLd, G. (eds), Mythologisches aus Eurasien im Ge-sar-Heldenepos der Tibeter. Ulm: Fabri Verlag.

1998. 'The Wonderful Deer in the Ge-sar Epic.' Pp. 53-56. In: VoGLiotTi, G. (trans.), Eurasian

Mythology in the Tibetan Epic of Ge-sar. Dharamsala: Library of Tibetan Works and Archives.

JACOBSON, E. 1983. 'Siberian Roots of the Scythian Stag Image.' Journal of Asian History 17: 68-120.

Köln: E. J. Brill. 1993. The Deer Goddess of Ancient Siberia: A Study in the ecology of belief. Leiden, New York and

JACOBSON-TEPFER, E. 2015. The Hunter, the Stag, and the Mother of Animals: Image, Monument, and Landscape in Ancient North Asia. Oxford: Oxford U. Press.

KARA, Gy. 1970. 'Une version ancienne de récit sur Geser changé en âne.' Pp. 213-246. In: LIGETI, L. (ed.), Mongolian Studies. Bibliotheca Orientalis Hungarica XIV. Amsterdam: B. R. Grüner; Budapest: Akadémiai Kiadó. . (ed.). 1971. A mongol irodalom kistükre (Mirror of the Mongolian Literature). Budapest: Európa Kiadó. KopPE, K. (transl. and comm.). 1993. Mongolische Epen XIII: „,Oiratische Epen“, 5 Epen aus Sinkiang. Wiesbaden: Harrassowitz Verlag.

Martynov, A. I. 1991. The Ancient Art of Northern Asia. D. B. Shimkin \& E. M. SHimkin (trans. and eds).

Urbana \& Chicago: University of Illinois Press.

MiERow, Ch. Ch. 1915. The Gothic History of Jordanes. Princeton: Princeton University Press; London: Humphrey Milford.

OnON, U. 2001. The Secret History of the Mongols: The Life and Times of Chinggis Khan. London and New York:

RoutledgeCurzon.

PEDERSEN, M. A. 2001. 'Totemism, Animism and North Asian Indigenous Ontologies.' The Journal of the Royal Anthropological Institute, 7 (3): 411-427. 
QI, L. and LIU, S. 1981. Zhongguo minjian gushi xuan (Popular Stories from China). Vol. 1. Beijing.

RichtSFELD, B. J. 2005. 'Gesar-Erzählungen der Yuguren (VR China).' Central Asiatic Journal 49 (2): 213-283.

SCHMIDT, I. J. 1839. Die Thaten Bogda Gesser Chans, des vertilgers der Wurzel der zehn Übel in den zehn Gegenden. Eine ostasiatische Heldensage. St. Petersburg: W. Gräff, [etc.].

STEIN, R. A. 1981 [1966]. 'Introduction to the Ge-sar Epic.' The Tibet Journal 6: (1): 3-13.

THOMPSON, S. 1955-1958. Motif-Index of Folk-Literature: A classification of narrative elements in folktales, ballads, myths, fables, medieval romances, exempla, fabliaux, jest-books, and local legends. Vols 1-6. Bloomington: University of Indiana Press.

TILLEY, Ch. 1991. Material Culture and Text: The art of ambiguity. London [etc.]: Routledge.

Uray-KöHalmi, K. 1980. 'Geser Khan in tungusischen Märchen.' Acta Orientalia Academiae Scientiarum Hungariacae 34: (1/3): 75-83.

VASILEVIČ, G. M. and Ja. N. AL'KOR (eds and trans.). 1936. Sbornik materialov po évenkijskomu (tungusskomu) fol'kloru. Leningrad: Izdatel'stvo istituta narodov severa CIK SSSR im. N. G. Smidoviča.

VITEBSKY, P. 1995. Shamanism. Norman: University of Oklahoma Press.

WALFORD, E. (trans.). 1855. The Ecclestical History of Sozomen. London: Henry G. Bohn.

ZERries, O. 1987. 'Lord of the Animals.' Pp. 22-26. In: Eliade, M. (ed.), The Encyclopedia of Religion, Vol. 9. New York: Macmillan Publishing Company; London: Collier Macmillan Publishers. 